\title{
Promotion of healthy eating at schools in the Federal District of Brazil ${ }^{1}$
}

\author{
Promoção da alimentação saudável: cenário \\ das escolas da capital do Brasil
}

Bethsáida de Abreu Soares SCHMITZ2,3

Maria de Lourdes Carlos Ferreirinha RODRIGUES 2,3

Cristine Garcia GABRIEL ${ }^{4}$

\section{A B S T R A C T}

\section{Objective}

The aim of the present study was to describe strategies for the Promotion of Healthy Eating at Public and Private Schools in the Federal District of Brazil.

\section{Methods}

A descriptive, analytical, cross-sectional study was carried out involving 122 Private Schools and 173 Public Schools. The components of health promotion in the school setting were adapted to the context of the promotion of healthy eating, with interviews conducted for the administration of a semi-structured questionnaire. The Student's $t$ test, Spearman's correlation coefficients and likelihood ratios were used for the statistical analysis ( $5 \%$ level of significance; $p<0.05$ ).

\section{Results}

Only one private elementary school fulfilled the criteria for 20 of the 24 items studied. At the other extreme, two public high schools only fulfilled the criteria for three items. A positive correlation was found between number of meetings held with the school community to address healthy eating and presence of healthy environments as well as between presence of healthy environments and monitoring of nutritional status of schoolchildren $(p<0.01)$. Schools that held an above-average number of meetings to address healthy eating had a smaller proportion of street vendors and local stores in the surrounding area $(p=0.01)$. The majority of

1 Article based on dissertation of JRM SILVA, entitled: "Health Promotion: Healthy eating in school context". Universidade de Brasília; 2010,

2 Universidade de Brasília, Faculdade de Ciências da Saúde, Programa de Pós-Graduação em Nutrição. Brasília, DF, Brasil.

${ }^{3}$ Universidade de Brasília, Núcleo de Pesquisa em Políticas Públicas, Observatório de Políticas de Segurança Alimentar e Nutricional. Brasília, DF, Brasil.

${ }^{4}$ Universidade Federal de Santa Catarina, Centro de Ciências da Saúde, Departamento de Saúde Pública. Campus Universitário Trindade, 88036-001, Florianópolis, SC, Brasil. Correspondence to/Correspondência para: CG GABRIEL. E-mails: <cris_ntr@hotmail.com>; <criggabriel@yahoo.com.br>.

Apoio: Ministério da Saúde (convênio OPSAN/MS 5562/2004). 
146 | JRM SILVA et al.

schools that had a partnership with healthcare professionals included the topic of healthy eating in the curriculum ( $p=0.04$ ).

\section{Conclusion}

The different associations found demonstrate the importance and interdependence of the components of the promotion of healthy eating. Preschools have developed more strategies for the Promotion of Healthy Eating and health in general in comparison to other teaching modalities. Schools in the Federal District of Brazil need support and training to be developed as a "Health Promoting School", specifically with regard to actions directed toward healthy eating.

Indexing terms: Health promotion. School feeding. Schools.

\section{RE S U M O}

\section{Objetivo}

Caracterizar as estratégias de Promoção da Alimentação Saudável em escolas públicas e privadas do Distrito Federal.

\section{Métodos}

Estudo transversal descritivo-analítico realizado com 122 escolas particulares e 173 públicas. Adaptaram-se os componentes de promoção da saúde no ambiente escolar para o contexto da Promoção da Alimentação Saudável, sendo realizadas entrevistas para a aplicação do instrumento. Os testes utilizados foram: $t$ de Student, coeficiente de correlação de Spearman e teste da razão de verossimilhança (nível de significância $p<0,05$ ).

\section{Resultados}

Apenas uma escola privada de ensino infantil contemplava positivamente 20 dos 24 itens pesquisados. No outro extremo, duas escolas públicas de ensino médio contemplavam apenas três itens. Observou-se correlação positiva entre o número de reuniões com a comunidade escolar para abordar a temática alimentação saudável e a presença de ambientes saudáveis e; entre a presença de ambientes saudáveis e o monitoramento do estado nutricional dos escolares $(p<0,01)$. As escolas que realizavam reuniões acima da média para abordar alimentação saudável possuíam em menor proporção ambulantes elou comércios locais próximos $(p=0,01)$. A maioria das escolas que possuíam parceria com profissional de saúde incluía a temática Alimentação Saudável no currículo $(p=0,04)$.

\section{Conclusão}

As diversas associações encontradas demonstram a importância e a interdependência dos componentes de Promoção da Alimentação Saudável estudados. As escolas de educação infantil desenvolveram mais estratégias de Promoção da Alimentação Saudável e da saúde em relação às demais modalidades. A maioria das escolas do Distrito Federal precisa de apoio e capacitação para desenvolver-se como Escola Promotora da Saúde, no recorte específico de ações voltadas para a alimentação saudável.

Termos de indexação: Promoção da saúde. Alimentação escolar. Instituições acadêmicas.

\section{INTRODUCTION}

International conferences on health promotion feature schools as the ideal setting for the development of actions aimed at encouraging healthy habits and lifestyles ${ }^{1}$. In the 1980s, the Health Promoting School initiative was established by the Pan American Health Organization (PAHO) and World Health Organization (WHO), consisting of an integral endeavor involving education, health and society. This action can be evaluated based on three interrelated components: 1) integral health education, 2) the creation and maintenance of healthy physical and psychosocial environments and 3) the offer of healthcare services, healthy eating and active living ${ }^{2-4}$. Experiences based on this proposal have been solidified in Brazil, as demonstrated by the development of actions that enable broadening the role of school meals in the promotion of health and nutrition education ${ }^{5}$. 
The promotion of healthy eating at school is based on an integral, multidisciplinary view that considers the school in its familial, community and social context $t^{6,7}$. The aim is to generate knowledge as well as develop skills and healthy attitudes by conducting educational opportunities in a critical, reflective fashion ${ }^{8}$. However, the relationship between knowledge and the adoption of healthy eating practices is complex and it is necessary for schools to be transformed into appropriate environments for the development of skills that can lead to healthy attitudes ${ }^{9}$. Moreover, schools cannot stand alone on this path and articulation with other sectors is essential to the success of such actions ${ }^{5}$.

The project entitled "Schools Promoting Healthy Eating Habits" was created in 2001 in the city of Brasilia, capital of Brazil. This project promotes healthy eating habits at public and private preschools and elementary schools in the Federal District. The project initially carried out play activities with students and delivered teaching material to schools, which was followed by actions for the training of educators and the heads of cafeterias ${ }^{10-12}$. In 2006, the project was restructured to include other actors in the school community (cooks, principals, coordinators, parents and members of the School Meal Council). Considering the recommendations of the $\mathrm{PAHO} /$ WHO for Health Promoting Schools, the project adopted the three components described for healthy eating strategies at basic education schools in the Federal District of Brazil.

The aim of this paper is to systematize this information, characterize healthy eating strategies at schools and contribute toward the effective planning of actions directed at the healthy eating and health promotion in the school setting.

\section{METHODS}

A descriptive, analytical, cross-sectional study was carried out between April 2008 and June 2009, involving Public and Private Schools. In 2006, the Federal District of Brazil had 589,969 students enrolled in 1061 public and private schools distributed among 30 administrative regions $^{13}$ (territorial areas the physical limits of which define the jurisdiction of governmental actions for the purposes of the administrative decentralization and the coordination of public services $)^{14}$.

For the sample calculation, the sampling procedure was stratified into public and private schools to ensure homogeneity with regard to the type of school. Simple, random sampling was then performed within each stratum for the selection of schools. Schools without updated registry data were excluded due to the impossibility of contacting possible participants. Thus, a universe of 607 Public Schools and 402 private schools was used, among which 287 schools were selected. Ninety-four additional schools were added to compensate for possible losses, totaling a sample of 381 schools.

The respondents were principals, coordinators and teaching advisers of the schools. In cases of refusal to participate, the school was replaced with another from a list planned for this purpose, with care taken for the replacement to be within the same stratum as the school it was replacing.

A semi-structured questionnaire was used for data acquisition and was composed of 48 open-ended and closed-ended questions divided into four datasets: 1) identification and characterization of the school; 2 ) participation of the school community in school activities; 3 ) presence of healthy environments; and 4) partnership with the health sector and monitoring of nutritional status. Datasets 2, 3 and 4 were based on the three components the PAHO recommends as the goals of schools considered to be "health promoting", adapted to the context of the promotion of healthy eating ${ }^{2,15-18}$. The variables were organized to address these components of interest (Chart 1). The participation of the school community was determined based on the number of meetings held with the community to address the issue of healthy eating and general topics, the collective, 
participatory drafting of the Teaching Policy Project and the inclusion of the issues of health and healthy eating in the school curriculum, totaling 10 variables. The presence of healthy environments included the existence and use of school spaces for the promotion of healthy eating (dining hall, site to post information, room for cooking classes, vegetable garden, commercial cafeteria and street vendors), totaling nine variables. The investigation of partnerships with the health sector (healthcare professionals, hospitals/health units and non-governmental organizations) and nutritional monitoring involved five variables (Chart 1).

A pilot test was carried out at four schools in the Federal District (two public and two private). Following telephone contact for scheduling, interviews were held for the administration of the questionnaire.

Descriptive and inferential analyses of the exploratory variables were performed based on the calculation of proportions with $95 \%$ confidence intervals. The Student's $t$ test was used for the comparison of means of meetings with the school community. Either Pearson's correlation coefficient or the Likelihood Ratio Test (depending on whether the variable was continuous or categorical) was used for the determination of differences between types of school (public vs. private or by teaching modality) regarding the number of positive items for the promotion of healthy eating. The Likelihood test is an alternative to Pearson's Chi-square test for associations between nominal variables. This test exhibits Chi-

Chart 1. Description of items evaluated for the development of participation of school community, healthy environments and partnership with health sector (including monitoring of nutritional status). Brasilia (DF), Brazil, 2008-2009.

\begin{tabular}{|c|c|c|}
\hline \multicolumn{2}{|c|}{ Components } & Items evaluated \\
\hline \multirow{3}{*}{$\begin{array}{l}\text { Participation of school } \\
\text { community }\end{array}$} & Meetings & $\begin{array}{l}\text { 1) Mean number of meetings with parents to address general topics. } \\
\text { 2) Mean number of meetings with parents to address healthy eating. } \\
\text { 3) Mean number of meetings with employees to address general topics. } \\
\text { 4) Mean number of meetings with employees to address healthy eating. }\end{array}$ \\
\hline & $\begin{array}{c}\text { Drafting of } \\
\text { Teaching Policy } \\
\text { Project }\end{array}$ & $\begin{array}{l}\text { 5) Suggestions from meetings considered in drafting of Teaching Policy Project. } \\
\text { 6) Involvement of school community in drafting of Teaching Policy Project. } \\
\text { 7) Involvement of teachers, coordinators and principals in drafting of Teaching Policy. } \\
\text { Project. } \\
\text { 8) Mean number of teachers involved in drafting of Teaching Policy Project. }\end{array}$ \\
\hline & School curriculum & $\begin{array}{l}\text { 9) Inclusion of healthy eating issue in school curriculum. } \\
\text { 10) Inclusion of health issues in school curriculum. }\end{array}$ \\
\hline \multicolumn{2}{|c|}{ Presence of healthy environments } & $\begin{array}{l}\text { 1) Dining hall with capacity to meet demand of students during meals. } \\
\text { 2) Specific site for publicizing information on health and healthy eating. } \\
\text { 3) Involvement of students in establishment of these specific sites. } \\
\text { 4) Permanent destination of these specific sites by the school. } \\
\text { 5) Place for cooking classes. } \\
\text { 6) School garden for promotion of healthy eating. } \\
\text { 7) Commercial cafeteria that promotes healthy eating. } \\
\text { 8) School cafeteria that produces meals provided by Secretary of Education and } \\
\text { promotes healthy eating. } \\
\text { 9) Absence of street vendors and local stores near school. }\end{array}$ \\
\hline \multicolumn{2}{|c|}{$\begin{array}{l}\text { Partnership with health sector and monitoring } \\
\text { of nutritional status }\end{array}$} & $\begin{array}{l}\text { 1) Monitoring of weight and height of students. } \\
\text { 2) Monitoring performed with all students. } \\
\text { 3) Partnership/voluntary participation with healthcare professional. } \\
\text { 4) Partnership with health unit or hospital. } \\
\text { 5) Partnership with other institutions that promote health and/or healthy eating. }\end{array}$ \\
\hline
\end{tabular}


squared distribution and is based on estimates by maximum likelihood. The non-parametric Gamma test was used to indicate the direction of the association between the components of healthy eating.

Teaching modality was categorized as Preschool, Elementary School and High School. As a given school could offer more than one teaching modality, the interpretation of the analyses was performed within each specific group, considering only the presence or absence of the modality. Thus, no summing of the crude numbers of each modality was performed. To evaluate constant items in each component, items related to cooks and the cafeteria that produces the school meals provided by the Secretary of Education were excluded, as such items only related to public schools. Moreover, frequencies higher than the means found in the sample were used to consider items regarding meetings with the school community and the mean number of teachers participating in the Teaching Policy Project as positive. The level of significance was set to $5 \%(p<0.05)$ in all analyses.

This study received approval from the Human Research Ethics Committee of the School of Health Sciences of the Universidade de Brasilia under protocol number 006/2005. All participants signed a Statement of Informed Consent.

\section{RES U L T S}

One hundred twenty-two private schools and 173 public schools participated in the study (total: 295 schools). Among the interviewees, $54 \%(n=151)$ were coordinators, $22 \%(n=63)$ were principals, $9 \%(n=25)$ were vice-principals and $15 \%(n=42)$ were categorized as "others". Schools with preschool classes $(59 \% ; n=172)$ and elementary school classes ( $55 \% ; n=162)$ had greater participation in the study.

At Public Schools, the mean number of students and teachers was $592 \pm 312$ and $58 \pm 11$, respectively. At Private Schools, the mean number of students and teachers was $319 \pm 267$ and $19 \pm 16$, respectively.

\section{Component: Presence of healthy environments at school}

Only five schools fulfilled all the items analyzed regarding this component, considering the specificities of the Public and Private Schools. Among these five schools, four offered the preschool modality, four offered the elementary school modality and all five offered the high school modality (Figure 1). Four of these schools were private. The mean number of items met for this component was three among the public schools and five among the Private Schools (Figure 2). Schools offering preschool or high school modalities had a greater number of positive items for the promotion of healthy eating in this component $(p<0.001)$.

The majority of schools $(72 \% ; n=211)$ did not have a dining hall large enough to meet the demands of students during meals. This environment was more prevalent in Private Schools $(60 \% ; n=53 ; p<0.001)$ and those offering the preschool modality $(p<0.001)$.

A total of $66 \%(n=194)$ of the schools had specific sites to publicize information on health and healthy eating. The prevalence of such sites was significantly greater in Public Schools $(p=0.003)$. However, a significant association with the permanent use of this educational space was found at Private Schools ( $p=0.03$ ). Most high schools had permanent sites to publicize information on health and healthy eating $(p=0.001)$. The vast majority of schools $(86 \% ; n=166)$ allowed students to participate in the assembly of these sites, especially schools offering the preschool modality $(p=0.005)$.

The presence of a commercial cafeteria was found in $46 \%(n=136)$ of the schools, with a significantly greater prevalence in public schools $(p=0.04)$. Commercial cafeterias were more concentrated in schools offering the elementary school modality $(n=120)$. The cafeteria was used 


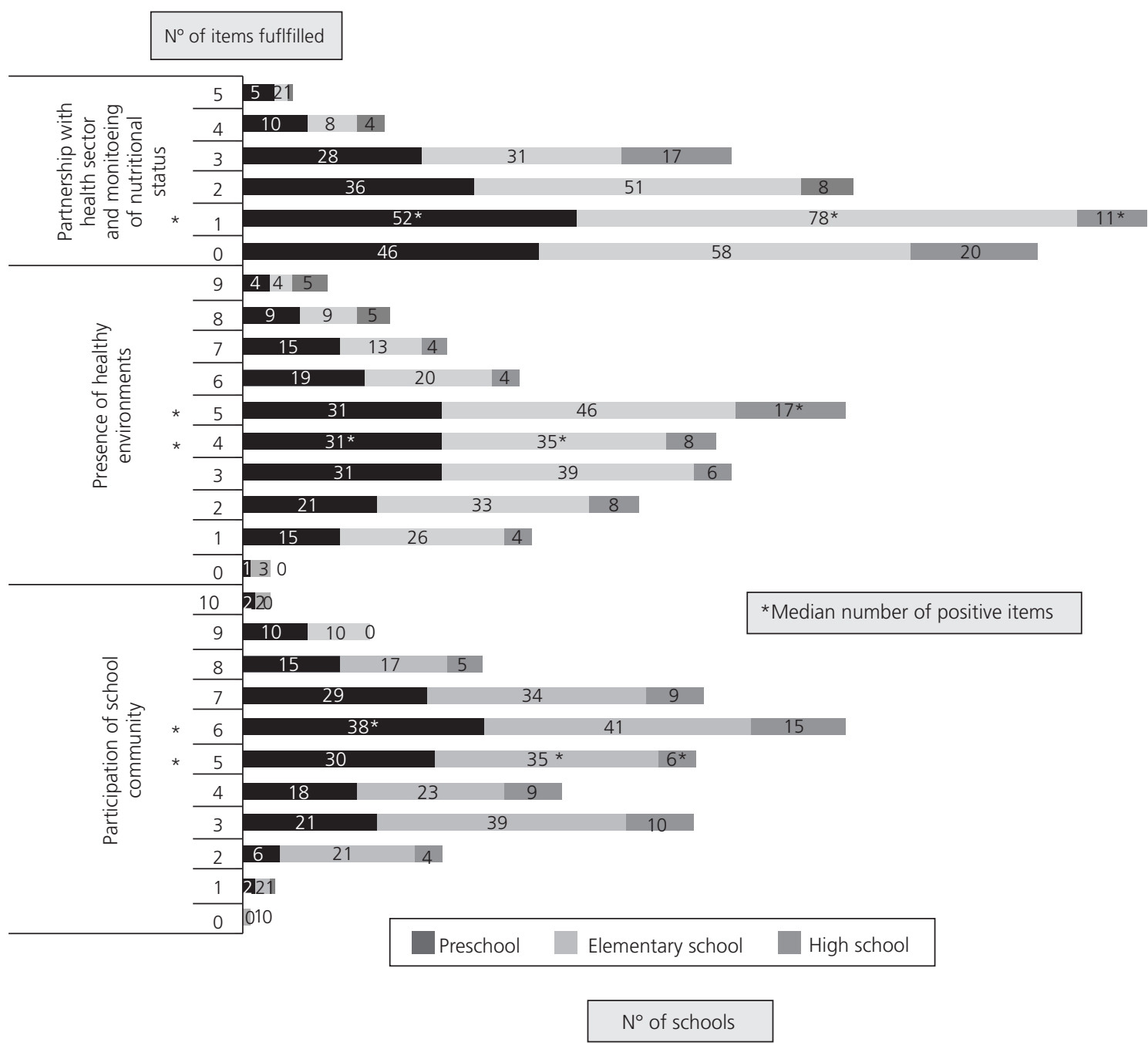

Figure 1. Characterization of schools according to fulfillment of items for the development of participation of school community, healthy environments and partnership with health sector (including monitoring of nutritional status) by teaching modality. Brasilia (DF), Brazil, 2008-2009.

as a place for the promotion of healthy eating in $59 \%(n=80)$ of the schools that had cafeterias. This type of use was significantly more prevalent in Private Schools $(p<0.001)$ and schools offering the preschool modality $(p=0.003)$. The presence of a school cafeteria that produces meals provided by the Secretary of Education was found in $82 \%$ $(n=142)$ of the Public Schools. Schools with a commercial cafeteria and a school cafeteria for the production of meals provided by the government accounted for $41 \%$ of the Public Schools $(n=70)$.

The presence of street vendors and local stores near the school (within 50 meters of the entrance) was found in $41 \%(n=121)$ of the schools. A greater concentration was found near public schools $(p=0.01)$ and those offering the elementary school modality $(n=105)$. Most of the schools offering the preschool modality did not have street vendors or local stores in the immediate surroundings $(n=115)$.

The majority of schools ( $61 \% ; n=180)$ had no place for cooking classes. Among the schools with a place for such activities, a greater number were Private Schools $(60 \% ; n=67 ; p<0.001)$ and those that offered the preschool modality $(p=0.005)$. The cafeteria (whether commercial or for the production of meals provided by the 


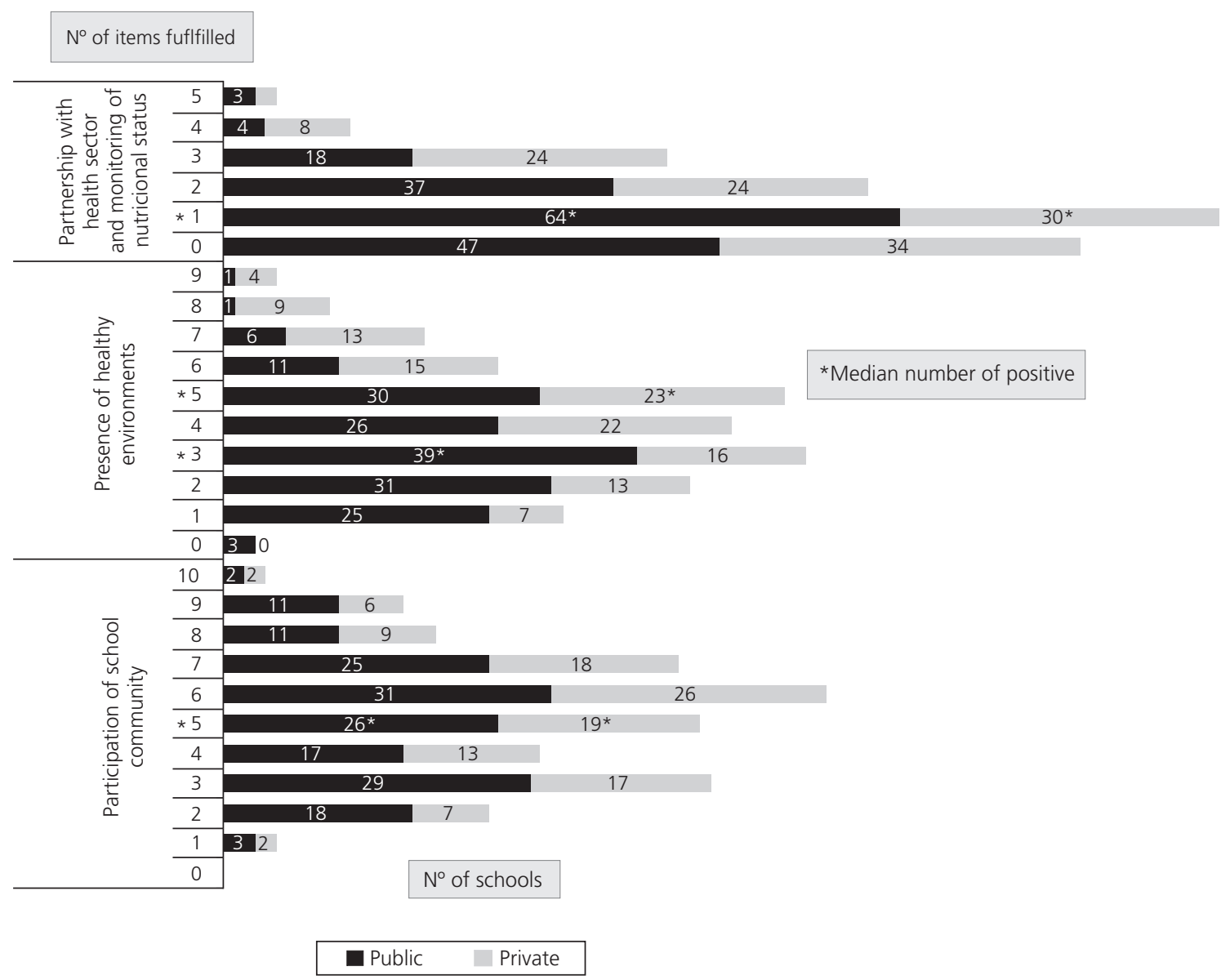

Figure 2. Characterization of schools according to fulfillment of items for the development of participation of school community, healthy environments and partnership with health sector (including monitoring of nutritional status) by type of school. Brasilia (DF), Brazil, 2008-2009.

government) was used in $23 \%(n=26)$ of the schools that had no other place for cooking classes. A vegetable garden was found in $34 \%$ $(n=100)$ of the schools and used for the promotion of healthy eating in $86 \%$ of cases. The majority of schools with a vegetable garden offered the preschool modality (72\%).

\section{Component: Participation of school community}

Only two preschools and two elementary schools fulfilled all ten variables related to this component (Figure 1). The median number of positive items was six in preschools and five in elementary schools. Public and private schools had a median of five positive items in this component (Figure 2). Schools offering the preschool modality had the highest number of positive items $(p=0.002)$.

At Public Schools, the mean number of meetings held per year to discuss the issue of healthy eating with parents and employees was one for each group. At Private Schools, these figures were 2.4 meetings/year with parents $(p=0.016)$ and 3.6 with employees $(p=0.004)$.

The suggestions raised during meetings with members of the school community were considered in the drafting of the Teaching Policy Project in $59 \%(n=175)$ of the schools, among which $57 \%(n=99)$ were Public Schools. Parents 
and employees were participants in the drafting of the project in $57 \%(n=169)$ of the schools. Teachers, coordinators and principals were participants in $92 \%(n=270)$ of the schools. Overall, these social actors had greater participation in the drafting of the project in public schools (60\%; $n=162)$.

A statistically significant difference was found in the mean number of meetings with parents on the issue of healthy eating between schools that included parents' suggestions in the drafting of the project and those that did not consider such suggestions $(p<0.001)$. The mean number of meetings per year was 2.5 in the former group and nearly zero (0.3) in the latter group.

Nine percent $(n=28)$ of the schools addressed all variables related to the drafting of the Teaching Policy Project. Eighteen of these schools were public schools, 18 offered the preschool modality and 24 offered the elementary school modality. The median number of positive items for the preschool and elementary school modalities was three. Regarding the type of school, the median number of positive items was three for public schools and two for private schools.

Ninety percent $(n=266)$ and $78 \%(n=230)$ of the schools included activities related to health and healthy eating in the curriculum, respectively, with greater frequencies found in the public schools in comparison to private schools $(p=0.001)$. Moreover, these topics were more prevalent in schools that offered the preschool modality $(p<0.001)$.

\section{Component: Partnership with health sector and monitoring of nutritional status of schoolchildren}

Only three public schools and two private schools fulfilled all items related to this component (Figure 2). These schools reported having partnerships with healthcare professionals, health units/hospitals and other institutions that promote health/healthy eating and performed nutritional monitoring. Twenty-seven percent $27 \%(n=81)$ of the schools did not perform any monitoring of the nutritional status of the students and had no partnerships with the health sector. The median number of positive items in the component was one for all teaching modalities (Figure 1) and both types of schools (Figure 2), indicating that the schools either had a partnership or performed nutritional monitoring.

Weight and height monitoring of the students was performed in 35\% $(n=103)$ of the schools, among which 62\% $(n=64)$ performed anthropometric evaluations on all students. The prevalence of anthropometric evaluations of all students was higher in private schools $(p=0.01)$. Moreover, this monitoring was more prevalent in schools offering the preschool modality (63\%; $n=45)$. Forty-six percent $(n=47)$ of the schools performed monitoring every semester and 31\% $(n=32)$ performed monitoring on an annual basis.

Partnerships with healthcare professionals were found in $40 \%(n=118)$ of the schools, with higher prevalence rates in public schools $(p=0.04)$ and those that offered the preschool modality $(p=0.01)$. The most commonly found health professional was a dentist (57\%; $n=67)$, followed by a nutritionist ( $45 \% ; n=53)$. Partnerships with physicians were significantly more prevalent in public schools $(p=0.017)$ and partnerships with nutritionists were significantly more prevalent in private schools $(p<0.001)$. A significant association was found between the monitoring of the nutritional status of all students and partnerships with a nutritionist $(p=0.004)$ and/or health unit/ hospital ( $p=0.017$ ). Besides this partnership, 34\% $(n=100)$ of the schools relied on the support of health units or hospitals, with a greater frequency among public schools ( $p=0.001)$.

\section{Joint evaluation of all three components}

None of the schools adequately fulfilled all 24 variables investigated as positive to the promotion of healthy eating. Only one private 
preschool fulfilled 20 items, which was the maximum number in the present study. At the other extreme, two public schools only fulfilled three items. Table 1 displays the mean number of items fulfilled for the three components. The analysis of the different teaching modalities revealed that schools offering the preschool modality had the greatest number of items evaluated as positive $(r=0.334 ; p<0.001)$.

Different associations were analyzed among the three components. Schools that included healthy eating in the curriculum held a greater number of meetings with parents (mean of 0.38 meetings among schools that included healthy eating in the curriculum versus 0.04 among those that did not include this subject; $p=0.001$ ) and employees (mean of 0.24 meetings among schools that included healthy eating in the curriculum versus 0.06 among those that did not include this subject; $p=0.005)$. This association demonstrates that the increase in the number of items promoting healthy eating in one group (inclusion of the issue in the curriculum) was accompanied by an increase in the other group (meetings with the school community) $(r=0.330$; $p<0.001)$. A positive correlation was also found between the number of meetings with the school community to address the issue of healthy eating and the presence of healthy environments $(r=0.249 ; p<0.001)$. Schools that held an aboveaverage number of meetings with the community to address healthy eating also had fewer street vendors and/or local stores in the proximities of the school $(r=0.282 ; p=0.001)$. The vast majority of schools that had partnerships with healthcare professionals included the issue of healthy eating in the curriculum $(p=0.04)$. Moreover, a positive correlation was found between the presence of healthy environments and the monitoring of the nutritional status of the students $(r=0.230$; $p<0.01)$.

Table 1. Characterization of schools according to fulfillment of items for the development of participation of school community, healthy environments and partnership with health sector (including monitoring of nutritional status) by teaching modality and type of school. Brasília (DF), Brazil, 2008-2009.

\begin{tabular}{|c|c|c|c|c|c|c|c|c|c|c|c|}
\hline \multirow{3}{*}{ Component } & \multirow{3}{*}{ Number of positive items } & \multicolumn{6}{|c|}{ Teaching modality } & \multicolumn{4}{|c|}{ Type of school } \\
\hline & & \multicolumn{2}{|c|}{ Preschool } & \multicolumn{2}{|c|}{ Elementary school } & \multicolumn{2}{|c|}{ High school } & \multicolumn{2}{|c|}{ Public } & \multicolumn{2}{|c|}{ Private } \\
\hline & & $\mathrm{N}$ & $\%$ & $\mathrm{~N}$ & $\%$ & $\mathrm{~N}$ & $\%$ & $\mathrm{~N}$ & $\%$ & $\mathrm{~N}$ & $\%$ \\
\hline \multirow{6}{*}{$\begin{array}{l}\text { Participation of } \\
\text { school community }\end{array}$} & 3 & 0 & 0 & 0 & 0 & 1 & 1.7 & 2 & 1.2 & 0 & 0 \\
\hline & 4 & 1 & 0.6 & 2 & 1 & 3 & 5.1 & 3 & 1.7 & 2 & 1.7 \\
\hline & 5 & 3 & 1.7 & 15 & 6.6 & 2 & 3.4 & 13 & 7.6 & 3 & 2.6 \\
\hline & 6 & 9 & 5.2 & 15 & 6.6 & 3 & 5.1 & 13 & 7.6 & 6 & 5.2 \\
\hline & 7 & 8 & 4.7 & 20 & 8.8 & 2 & 3.4 & 15 & 8.7 & 6 & 5.2 \\
\hline & 8 & 9 & 5.2 & 17 & 7.5 & 2 & 3.4 & 18 & 10.5 & 4 & 3.4 \\
\hline \multirow[t]{2}{*}{+} & 9 & 23 & 13.4 & 28 & 12.4 & 4 & 6.8 & 24 & 14.0 & 11 & 9.5 \\
\hline & 10 & 23 & 13.4 & 25 & 11.1 & 4 & 6.8 & 19 & 11.0 & 16 & 14.0 \\
\hline \multirow[t]{2}{*}{ Healthy environments } & 11 & 16 & 9.3 & 24 & 10.6 & 9 & 15.3 & 18 & 10.5 & 11 & 9.5 \\
\hline & 12 & 15 & 8.7 & 15 & 6.6 & 5 & 8.5 & 10 & 5.8 & 8 & 7.0 \\
\hline \multirow[t]{2}{*}{+} & 13 & 16 & 9.3 & 13 & 5.8 & 3 & 5.1 & 9 & 5.2 & 11 & 9.5 \\
\hline & 14 & 10 & 5.8 & 17 & 7.5 & 7 & 12.0 & 10 & 5.8 & 8 & 7.0 \\
\hline \multirow{8}{*}{$\begin{array}{l}\text { Partnership with } \\
\text { health sector and } \\
\text { monitoring of } \\
\text { nutritional status }\end{array}$} & 15 & 10 & 5.8 & 12 & 5.3 & 3 & 5.1 & 10 & 5.8 & 6 & 5.2 \\
\hline & 16 & 9 & 5.2 & 6 & 2.7 & 3 & 5.1 & 2 & 1.2 & 9 & 7.8 \\
\hline & 17 & 12 & 7 & 10 & 4.4 & 4 & 6.8 & 5 & 3.0 & 8 & 7.0 \\
\hline & 18 & 4 & 2.3 & 4 & 1.8 & 2 & 3.4 & 1 & 0.6 & 3 & 2.6 \\
\hline & 19 & 3 & 1.7 & 3 & 1.3 & 2 & 3.4 & 0 & 0 & 3 & 2.6 \\
\hline & 20 & 1 & 0.6 & 0 & 0 & 0 & 0 & 0 & 0 & 1 & 1.0 \\
\hline & Total number of schools & 172 & 100 & 226 & 100 & 59 & 100 & 172 & 100 & 116 & 100 \\
\hline & $\begin{array}{c}\text { Median number of } \\
\text { positive items }\end{array}$ & 11 & - & 10 & - & 11 & - & 9 & - & 11 & - \\
\hline
\end{tabular}




\section{DISCUSSION}

The present findings reveal heterogeneity among schools regarding the components of the promotion of healthy eating, making it necessary to considered specificities in the planning and development of strategies for promoting healthy eating in the school setting. Some of the actions necessary for these schools are found stipulated in Directive 1010 ${ }^{19}$, issued in 2006 by the Brazilian Ministries of Education and Health and recognized as a first step in the establishment of guidelines for the promotion of school health on the national level. Despite this directive, the schools studied in the Federal District need support for their development as a Health Promoting School, which justifies national and international governmental efforts directed toward the development of financial and educational mechanisms as well as additional support to potentiate the establishment of Health Promoting Schools ${ }^{20,21}$.

To strengthen health promoting actions in Brazilian schools, the effective institutionalization of the "Health at School Program" 20 created in 2007 is needed through the formulation of health policies with and for the educational community as well as the participation of key social actors in the management of the program, the strengthening of technical capacities, research and the mobilization of resources.

The school profile with the greatest number of variables considered significant for the promotion of healthy eating was the private school and the preschool teaching modality. The importance of initiating health promotion actions in the early years of life is unquestionable. However, children aged five years or older are habitually excluded from priority strategies of official health and education policies, despite being biologically, nutritionally and socially susceptible to health problems ${ }^{22,23}$.

Sichieri \& Souza ${ }^{24}$ performed a review on obesity prevention in children and adolescents and found that interventions were more effective in elementary and high schools. The positive results with adolescents may be explained by the fact that individuals in this age group are more capable of assimilating the intervention material and administrate their choices better.

According to Inter-Ministerial Directive 1010/2006, schools should develop family information strategies, emphasizing coresponsibility in the promotion of healthy eating ${ }^{19}$. Moreover, the participation of the school community in actions developed at schools is one of the requirements for the classification of a Health Promoting School ${ }^{2}$. While the majority of schools analyzed in the Federal District reported holding meetings with parents to address this issue, the mean number of meetings was very low $^{8}$. Despite the few meetings, the associations found between the components and the number of meetings evidence the importance of this action for the acquisition or modification of other items. Moreover, there is evidence that the consistent participation of parents in the school process favor the self-confidence and satisfaction of parents with the school and helps enhance the motivation, attitudes and behavior of the students in the classroom ${ }^{25}$. Benefits have also been reported regarding the health and wellbeing of students, such as an increase in physical activity, improved eating patterns and enhanced knowledge on the prevention of diabetes and obesity 26,27.

Regarding the drafting of the Teaching Policy Project, Public Schools carried out this process in a collective, participatory fashion. Federal programs underway since 2004 develop actions to strengthen school councils throughout the country. When aggregated to the Teaching Policy Project, the aim of such actions is to contribute toward more democratic, civic-minded schools. This subject merits investigation in light of the importance of the drafting of the Teaching Policy Project with regard to the inclusion and discussion of the issues of health and healthy eating ${ }^{28}$.

The majority of schools reported including the issues of health and healthy eating in the curriculum, but it is not known whether the 
inclusion of these issues occurs in a continual, cross-sectional, interdisciplinary fashion, as established in the National Curriculum Parameters ${ }^{29}$. An important aspect related to the Teaching Policy Project and curricular actions regards the difficulty educators have in placing what is proposed in the project into daily practice. Therefore, it is necessary to invest in health education for the social actors of the school community in order to strengthen the active exercise of actions aimed at the promotion of healthy eating.

Due to the methodological design of the present study, the origin of the positive association between the inclusion of the healthy eating issue and the existence of meetings with parents and employees to address this issue is not known. However, the results indicate the concern of the school community with the issue of healthy eating, as epidemiological data on excess weight and chronic diseases has increased among Brazilian schoolchildren ${ }^{30}$.

Regarding the creation and use of healthy environments, information offered in the classroom should be complemented with activities that occur outside the classroom, such as dining halls, which are recognized for their importance in health promotion strategies directed at schoolchildren ${ }^{19}$. Few schools in the Federal District have all environments considered to promote healthy eating. Moreover, the participation of the school community proved to have a protective effect for the presence of healthy environments and the absence of unhealthy environments.

In two years of the Efficient School Meal Manager Prize, the number of candidate municipal governments with schools containing a dining hall reached more than $80 \%$. A dining hall for school meals is more than merely a place to eat; it is also a place for socialization among students and teachers and the promotion of healthy eating practices ${ }^{31}$. The manner by which school meals are addressed is related to the guaranty of basic human rights. The existence of school meals implicitly transmits to students the notion that all have the right to a nutritionally adequate diet and to make meal time a sociocultural act of companionship and pleasure.

The establishment of a school vegetable garden is another important initiative for the promotion of healthy eating. Among candidate schools for the aforementioned prize, vegetable gardens were found in 2,145 schools $(25 \%$ of the total) in 2004 and 1,560 schools (30\% of the total) in $2005^{31}$. The present study found a similar percentage of vegetable gardens used for the promotion of healthy eating. However, it should be stressed that the existence of a vegetable garden per se does not necessarily signify its use for the promotion of healthy eating. Communication with the school community is needed for the development of teaching activities and caring for the garden.

Projects that allow children to handle foods and try new flavors and textures can contribute toward adequate eating choices. This is an important issue for the school community to consider, especially at public schools, as less than half of the schools analyzed had a place for cooking classes. With the increase in the consumption of processed foods in the Brazilian population, it is common to find children and adolescents who are unaware of certain types of food, especially fruits and vegetables. Thus, actions that allow direct contact with these foods can assist in the promotion of healthy eating in the school setting.

Sites for the posting of information on health and healthy eating were found in a large portion of the schools. When used in combination with other health promoting actions, this simple strategy can be used to foster the involvement of the school community, allowing access to healthy practices and socio-cultural aspects of dietary habits.

The prevalent presence of a commercial cafeteria at public elementary schools is a particular concern. Besides existing alongside the cafeteria that provides free meals from the 
Brazilian National School Meal Program, its use for the promotion of healthy eating was cited little. According to Sturion et al. ${ }^{32}$, the presence of commercial cafeterias is inversely associated with daily adherence to the national meal program. The authors also report the considerable presence of street vendors and local stores near public elementary schools. A number of regional laws regulating sales in commercial cafeterias have been issued in Brazil ${ }^{33}$. Specifically in the Federal District, District Law n 3,695 addressing the promotion of healthy eating in Public and Private Schools went into effect in $2006^{34}$, but was revoked in March of the same year. The findings of the present study and previously cited epidemiological data indicate the need for policies that involve the owners of commercial cafeterias.

The component partnership with the health sector and monitoring of nutritional status was addressed little at the schools. The study design does not allow determining whether this partnership is structured as a public health program, in which the objectives are not limited to the immediate care of health problems among the students, but seek to ensure the rights of children and adolescents to benefit from actions organized in the collective realm. A positive association was found between the monitoring of nutritional status and the presence of healthy environments. Proper nutritional diagnoses are important to outlining the needs of the population at each school ${ }^{20}$, allowing a precise determination of the magnitude, behavior and determinants of nutritional problems as well as the identification of groups at risk and adequate interventions ${ }^{17,26}$. In the present study, public schools that offer the preschool modality prioritize the monitoring of weight and height among preschoolers. However, other age groups also require such monitoring. The Brazilian National School Health Survey reports prevalence rates of $18 \%$ and $5 \%$ for overweight and obesity among ninth grade students ${ }^{30}$.

The positive association between partnerships with healthcare professionals and the inclusion of the issue of healthy eating in the curriculum suggests an exchange of knowledge that can potentiate classroom activities. For such, it is necessary for educators to undergo training in health education. Actions with this purpose should include ongoing nutritional education to allow knowledge building and the determination of local needs. Such training could also allow educators to establish dynamic classroom activities with their students.

\section{FINAL CONSIDERATIONS}

The different associations found in the present study demonstrate the importance and interdependence of the different components for the promotion of healthy eating. However, this field of knowledge needs to be explored through further in-depth studies for a better understanding of the issues involved.

Preschools were found to develop more strategies for the promotion of health and healthy eating. However, it is essential to encourage these initiatives in other teaching modalities, as epidemiological data demonstrate that adolescents increasingly exhibit unhealthy living habits. Reflections on this issue should be carried out by all social actors involved, such as members of the school community and administrators in charge of the establishment of policies and strategies aimed at encouraging healthier lifestyles. The majority of schools in the Federal District of Brazil require support and training in order to become Health-Promoting Schools with regard to the encouragement of healthy eating.

\section{CONTRIBUTORS}

JRM SILVA contributed to conception and development of study, data analysis and drafting of manuscript. BAS SCHMITZ and MLCF RODRIGUES contributed to conception and development of study, data analysis, drafting of manuscript and revision of final version. CG Gabriel contributed to drafting of manuscript and revision of final version; author responsible for negotiations. 


\section{REFEREN CES}

1. Brasil. Ministério da Saúde. Secretária de Políticas de Saúde. Projeto promoção da saúde: as cartas da promoção da saúde. Brasília: MS; 2002.

2. Ippolito-Shepherd J, Cerqueira MT, Ortega DP. Iniciativa regional escuelas promotoras de la salud en las Américas. Inter Union Health Promo Educ. 2005; 12(3-4):220-9.

3. Figueiredo TAM, Machado VLT, Abreu MMS. A saúde na escola: um breve resgate histórico. Ciênc Saúde Coletiva. 2010; 15(2):397-402. doi: 10.159 0/S1413-81232010000200015.

4. Cunha E, Sousa AA, Machado NMV. A alimentação orgânica e as ações educativas na escola: diagnóstico para a educação em saúde e nutrição. Ciênc Saúde Coletiva. 2010; 15(1):39-49. doi: 10.1590/S14 13-81232010000100009.

5. Brasil. Ministério da Saúde. Escolas promotoras de saúde: experiências do Brasil. Brasília: MS; 2006.

6. Manios Y, Moschandreas J, Hatzis C, Kafatos A. Health and nutrition education in primary schools of Crete: Changes in chronic disease risk factors following a 6-year intervention programme. $\mathrm{Br}$ J Nutr. 2002; 88(3):315-24.

7. Gaglianone CP, Taddei JAAC, Colugnati FAB, Magalhães CG, Davanço GM, Macedo L, et al. Educação nutricional no ensino público fundamental em São Paulo, Brasil. Projeto reeducação aos riscos de adoecer e morrer na maturidade. Rev Nutr. 2006; 19(3):309-20. doi: 10.1590/S1415-\$27320 06000300002.

8. Focesi E. Educação em saúde na escola: o papel do professor. Rev Bras Saúde Esc. 1990; 1(2):4-8.

9. Somerset S, Markwell K. Impact of a school-based food garden on attitudes and identification skills regarding vegetables and fruit: A 12-month intervention trial. Public Health Nutr. 2008; 12(2):214-221.

10. Schmitz BAS, Recine E, Cardoso GT, Silva JRM, Amorim NFA, Bernardon R, et al. A escola promovendo hábitos alimentares saudáveis: uma proposta metodológica de capacitação para educadores e donos de cantina. Cad Saúde Pública. 2008; 24(Supl 2):312-22. doi: 10.1590/S0102-311X20 08001400016.

11. Bernardon R, Silva JRM, Cardoso GT, Monteiro RA, Amorim NFA, Schmitz BAS, et al. Construção de metodologia de capacitação em alimentação e nutrição para educadores. Rev Nutr. 2009; 22(3): 389-98. doi: 10.1590/S1415-52732009000300 009.

12. Yokota RTC, Vasconcelos TF, Pinheiro ARO, Schmitz BAS, Coitinho DC, Rodrigues MLCF. Projeto "A es- cola promovendo hábitos alimentares saudáveis": comparação de duas estratégias de educação nutricional no Distrito Federal, Brasil. Rev Nutr. 2010; 23(1):37-47. doi: 10.1590/S1415-527320 10000100005 .

13. Distrito Federal. Cadastro de instituições educacionais do Distrito Federal: censo escolar de 2006. Brasília: Governo do Distrito Federal; 2006.

14. Distrito Federal. Projeto Memória. $11^{\text {a }}$ Ed. Brasília: Governo do Distrito Federal; 2003. [acesso 2011 nov 14]. Disponível em: <http://www.gdf.df. gov.br/045/04501018.asp>.

15. Organización Panamericana de La Salud. Promoción y educación de la salud escolar, una perspectiva integral: marco conceptual y operativo. Washington (DC): OPAS; 1995.

16. Organización Panamericana de La Salud. Educación para la salud: un enfoque integral. Washington (DC): OPAS; 1995. Série HSS/SILOS, n.37.

17. World Health Organization. School Health Promotion-Series 5: Regional guidelines: Development of Health Promoting Schools: A framework for action. Washington (DC): WHO; 1996.

18. Lawrence STL. Reducing the barriers to the expansion of health-promoting schools by focusing on teachers. Health Educ. 2000; 100(2):81-7.

19. Brasil. Portaria interministerial $n^{\circ} 1.010$, de 8 de maio de 2006. Institui as diretrizes para a promoção da alimentação saudável nas escolas de educação infantil, fundamental e nível médio das redes públicas e privadas, em âmbito nacional. Diário Oficial da União. 2006 maio 9.

20. Brasil. Decreto presidencial $n^{\circ} 6.286$, de 5 de dezembro de 2007. Institui o Programa Saúde na Escola - PSE, e dá outras providências. Diário Oficial da União. 2007 dez 6.

21. Rana L, Alvaro R. Applying a Health Promoting Schools approach to nutrition interventions in schools: Key factors for success. Health Promot J Austr. 2010; 21(2):150-69.

22. Cyrino EG, Pereira MLT. Reflexões sobre uma proposta de integração saúde-escola: o projeto saúde e educação de Botucatu, São Paulo. Cad Saúde Pública. 1999; 15(Supl 2):39-44. doi: 10.1590/S0 102-311X1999000600005.

23. Bizzo MLG, Leder L. Educação nutricional nos parâmetros curriculares nacionais para o ensino fundamental. Rev Nutr. 2005; 18(5):661-7. doi: 10.1590/S14 15-52732005000500009.

24. Sichieri R, Souza RA. Estratégias para prevenção da obesidade em crianças e adolescentes. Cad Saúde Pública. 2008; 24(Supl 2):S209-S34. doi: 10.1590/S0 102-311X2008001400002. 
25. Garcia-Dominic O, Wray LA, Treviño RP, Hernandez $A E$, Yin $Z$, Ulbrecht J $S$. Identifying barriers that hinder onsite parental involvement in a schoolbased health promotion program. Health Promot Pract. 2010; 11(5):703-13.

26. Treviño RP, Hernandez AE, Zenong Y, Garcia O, Hernandez I. Effects of the Bienestar health program on physical fitness in low-income Mexican American children. Hispanic J Behav Sciences. 2005; 27(1):120-32. doi: 10.1177/07399863042723 59.

27. Treviño RP, Yin Z, Hernandez A, Hale DE, Garcia OA, Mobley C. Impact of the Bienestar schoolbased diabetes mellitus prevention program on fasting capillary glucose levels: A randomized controlled trial. Arch Pediatr Adolesc Med. 2004; 158(9):911-7.

28. Brasil. Ministério da Educação. Portaria $n^{\circ} 2.896$, de 17 de setembro de 2004. Cria o Programa Nacional de Fortalecimento de Conselhos Escolares. Diário Oficial da União. 200417 set; (180):7; Seção 2.

29. Brasil. Ministério da Educação. Parâmetros curriculares nacionais: terceiro e quarto ciclos: apresentação dos temas transversais. Brasília: MEC; 2001.
30. Instituto Brasileiro de Geografia e Estatística. Pesquisa nacional de saúde do escolar. Rio de Janeiro: IBGE; 2009.

31. Belik W, Chaim NA. O programa nacional de alimentação escolar e a gestão municipal: eficiência administrativa, controle social e desenvolvimento local. Rev Nutr. 2009; 22(5):595-607. doi: 10.15 90/S1415-52732009000500001.

32. Sturion G, Silva MV, Ometto AMH, Furtuoso COM, Pipitone MAP. Fatores condicionantes da adesão dos alunos ao Programa de Alimentação Escolar no Brasil. Rev Nutr. 2005; 18(2):167-81. doi: 10.15 90/S1415-52732005000200001.

33. Brasil. Ministério da Saúde. Experiências estaduais e municipais de regulamentação da comercialização de alimentos em escolas no Brasil: identificação e sistematização do processo de construção e dispositivos legais adotados. Brasília: MS; 2007.

34. Brasil. Lei n 3.695, 8 de novembro de 2005. Dispõe sobre a promoção da alimentação saudável nas escolas da rede de ensino do Distrito Federal. Diário Oficial da Câmara Legislativa. 2005 nov 8.

Received on: 24/2/2012

Final version on: $11 / 10 / 2012$

Approved on: 12/11/2012 